\title{
Effect of Folic Acid by injection and supplementary on growth and puberty of Karadi male lambs.
}

\author{
Ismael Othman Karim \\ Animal Sciences \\ College of Agricultural Engineering Sciences \\ University of Sulaimani \\ Sulaymaniyah, Iraq \\ ismaelo.karem@gmail.com
}

\author{
Chowman Aladdin Omar \\ Animal Sciences \\ College of Agricultural Engineering Sciences \\ University of Sulaimani \\ Sulaymaniyah, Iraq \\ Choman.omer@univsul.edu.iq
}

\section{Article Info \\ Volume 6-Issue 1- June 2021 \\ DOI: \\ 10.24017/science.2021.1.5}

\section{Article history:}

Received 3/3/2021

Accepted 24/4/2021

\section{Keywords:}

Folic Acid, Karadi male lamb, Tests volume, Testosterone.

\begin{abstract}
The present study is carried out to study the effect of Folic Acid (FA) by injection and supplementary on animal body weight gain, Tests volume before slaughtering, Testes volume after slaughtering, Testosterone concentration in blood and FA concentration in blood. Twenty-five (25) Karadi male lambs five months aged and the average weight was $24.54 \pm 1.92 \mathrm{~kg}$ was used in this experiment. The animals weighted after three months of treatment to get animal increased live weight, The testes measured after one, two, and three months of treatment to calculate testes volume, testosterone, and FA concentration level in the blood were taken after one, two, and three months of treatment. The present study demonstrated that animal body weight, animal body weight gain, and total body weight gain significantly not increased $(p>0.05)$. Testicular length, and testicular circumference not increased $(p>0.05)$ after $1^{\text {st }}, 2^{\text {nd }}$, and $3^{\text {rd }}$ months after treatment, and after slaughtering. However, testicular high increased $(p<0.05)$ after each month of treatment and slaughtering. Testosterone concentration in blood significantly not different $(p>0.05)$ reported between treatments after $1^{\text {st }}, 2^{\text {nd }}$, and $3^{\text {rd }}$ months of treatment. FA concentration in blood significantly increased $(p<0.05)$ when used 3 and $6 \mathrm{mg}$ FA by injection compared to control after $1^{\text {st }}$ and $2^{\text {nd }}$ month of treatment. However, blood FA concentration increased $(p<0.05)$ when used FA $6 \mathrm{mg} / \mathrm{ml}$ as injection after $2^{\text {nd }}$ month of treatment compared to control. While using FA by supplementation and injection significantly $(p>0.05)$ on the diameter and circumference of seminiferous tubules, germ cells thickness, and lumen diameters.
\end{abstract}




\section{INTRODUCTION}

Sheep and goats have spread throughout the world and were domesticated about 11,000 years ago in southwest Asia [1]. Sheep own a high capacity to adaptation in different environmental condition, which it has allowed to survive in the desert, semi-desert and cold mountain region, $20 \%$ of sheep population in the world are placed in the tropical and semi-tropical region, the main purpose of raising sheep is to meat production, and a less degree milk, wool, skin, and manure [2]. Sheep have great adaptability with environments, short production cycle, fast growth rate, easy to manage, and low investment, feed requirement if compared to a large ruminant, they are a critical source of protein of the poor people, give extra income, and support survival for many farmers [3]. Sheep are raised for four major products: meat, milk, wool/hair, and skin. Meat is the major sheep product in many parts of the world especially the temperate region, this caused increasing meat production [4]. The meat of sheep has complex structure include water $(73 \%)$, protein $(21 \%)$, lipid $(5 \%)$, Carbohydrates, many vitamins and mineral present a smaller amount, The water, protein, and fat content can be affected by hereditary, feeding background, and age [5]. Because of animal protein consist of all essential amino acids for human body needs efficiently, and recommended daily intake for an adult person at least 60 $\mathrm{g}$ of animal protein and 800-1000 mg calcium daily, so the milk of sheep is the best source of protein and calcium for human [6]. Karadi sheep are recognized to be the largest among the local breeds that are raised in the mountainous region in Kurdistan of Iraq. The Most Important and favored strain of Karradi sheep among sheep owners Is Hamdani sheep, because of High rate of twinning, large body frame, High production of milk, and fleece weight are heavy [7].

Folic acid is a one vitamin of the vitamin B complex that involves one-Carbone compound metabolism [8]. FA is a water-soluble plays an important role in the synthesis of DNA, stability and integrity, and repair [9]. FA is important for the synthesis of DNA, RNA, and protein, hence it is essential for all tissues and essential for growth and cellular division with a high rate [10]. Folate is the generic name for compounds family including FA, and its derivative such as 5MTHF, 5-formyltetrahydrofolate (5-FTHF or folinic acid), 5,10-methylen-THF, 10 formylTHF, and unsubstituted THF Folate[11]. In the structure of 5-methyltetrahydrofolate (5-MTHF) participate in the remethylation of homocysteine to methionine, which precursor Sadenosylmethionine (SAM), the primary methyl group donor for most biological methylation reaction including DNA methylation, after transferring methyl group, SAM is changed to Sadenosylhomocystiene (SAH) [9]. FA participates in Amino Acid metabolism and purines and pyrimidines synthesis [12]. FA acts as an acceptor and donor of one Carbone unit and involved in cell division [13]. A deficiency of FA Causes impaired cell division, protein synthesis, and growing tissues [14]. The deficiency of FA in the diet of rats before breeding induces on reducing of the number of live births, Average litter size and birth weight of the offspring, this directly related inability synthesis of protein normally because of rats deficiency to FA [12]. Supplementing FA during pregnancy increases the weight of neonate and the muscle fiber morphologically changes with supplementation of their mothers' diet in the sheep [15]. FA effects on increasing body weight, relative weight of testis, plasma testosterone concentration, and epididymis in male New Zealand white rabbits [16]. Adding FA to the dietary of calve causes improving Nutrient income, the performance of growth, and the efficiency of feed [17]. FA supplementary influences to increase hemoglobin and packed cell volume in the calf [14]. [10] Used FA as supplementation for dairy calves and reported that FA as supplementation caused to increase the red blood cells, folate concentration, and increasing folate in serum and hepatic, as well as blood hemoglobin and packed cell volume increased but slightly decreased with age. So, our main aim of this study is to compare between injection and feed supplementation of FA and their effect on growing lams and their puberty.

\section{METHODS AND MATERIALS}

This study was carried out at the experimental farm of Animal Sciences department Agricultural Engineering Sciences College, during spring (April to July) 2019. 
Twenty-five (25) Karadi male lambs five months aged and the average weight was $24.54 \pm 1.92 \mathrm{~kg}$. The lambs weighted to get initial weight and they treated by FA for 3 three months to the experiment for three months. They divided into five treatment groups, 5 lambs in each treatment $(\mathrm{r}=5)$. The treatments included: (T1) control (without treatment), (T2, T3) supplemented 3, $6 \mathrm{mg}$ FA as capsule/week, (T4, T5) intramuscularly injected $3,6 \mathrm{mg} / \mathrm{ml}$ per week. Before began the experiment, all lambs injected subcutaneously by profiverm $1 \%(1 \mathrm{ml}$ for each lamb) to the internal and external parasites. The lambs fed barley $0.5 \%$ of their weight daily, increased gradually barley to reach adaptive $1.5 \%$ of lamb's weight for one month to avoid digestive disorder, and fed ad-libtum on straw. The weight of animals weekly recorded to investigate the growth characteristic: feed intake ratio, Feed conversation ratio, and Daily gain weight. The blood collected 3 times during the experiment (after each month) and sent to the laboratory to determine RBC Count, Plasma biochemical parameters, Differential WBC, H/L ratio, Testosterone concentration, WBC Count. Tests parameter have externally measured monthly during the experiment. At the end of the experiment 15 animals $(r=3)$ chosen in each group randomly and slaughtered to record the testis parameter: testicular length, width, high and circumference, and to measure length of the epididymis, testis Histological Parameters, and to measure the male reproductive tract.

FA solution preparation for injection:

1. Prepare $2 \mathrm{~N}$ sodium hydroxide.

2. Weight $30 \mathrm{mg}$ or $60 \mathrm{mg}$ FA progressively for (FA $3 \mathrm{mg} / \mathrm{ml}$ or $6 \mathrm{mg} / \mathrm{ml}$ ).

3. Add drop drop sodium hydroxide on FA until it dissolves completely.

4. Add $12 \mathrm{mg}$ EDTA for FA injection $3 \mathrm{mg} / \mathrm{ml}$, and $24 \mathrm{mg}$ EDTA for FA injection 6 $\mathrm{mg} / \mathrm{ml}$.

5. Add $90 \mathrm{mg}$ benzyl alcohol for FA injection $3 \mathrm{mg} / \mathrm{ml}$ and $180 \mathrm{mg}$ for FA injection $6 \mathrm{mg} / \mathrm{ml}$, and stir for one or two hours.

6. Adjust PH between (8 and 11).

7. Complete volume with distil water to $10 \mathrm{ml}$.

8. Filter the solution.

Data were analyzed statistically by Complete Random Design (CRD) using (IBM SPSS, STAT. 23.0, 2018) software. Moreover, the treatment deference's were determined by using Duncan Test at $(\mathrm{P} \leq 0.05)$.

\section{RESULTS AND DESCUSSION}

The results of Body weight $(\mathrm{BW})$, body weight gain $(\mathrm{BWG})$ after $1^{\text {st }}, 2^{\text {nd }}$, and $3^{\text {rd }}$ months of experiment, and total body weight gain (BWGT) are demonstrated in Table (1). The table showed that there are no significant differences $(p>0.05)$ observed in the BW, BWG, and BWGT. While BW, BWG, and BWGT in all treatments increased if compared to the control, but not significantly, except BW and BWG after one month of treatment 5 less than control. FA has a great role in DNA synthesizing and cell division [18]. Therefore, FA aspects that have a great role in Animal weight and. But FA metabolism in brain effects neuropeptides and neurotransmitters and causes inhibiting the action them, (like gammaamino butyric acid), that responsible for controlling feed intake [19]. This reason may be the main factor that no different observed significantly in BW, BWG, and BWGT. Our result agree with the result that experimented on gilts and reported that Using FA $5 \mathrm{mg} / \mathrm{kg}$ diet and FA $15 \mathrm{mg} / \mathrm{kg}$ diet from 9 to 21 weeks of age were not influenced on body weight and growth performance during overall growing period [20]. 
Table 1: Effect of different FA treatments by supplementation and injection on Animal weight and Animal increased weight of local Karadi male lambs (Mean \pm SE).

\begin{tabular}{|c|c|c|c|c|c|}
\hline Treatments & BW (kg) & BWG 1 (kg) & BWG 2 (kg) & BWG 3 (kg) & $\begin{array}{l}\text { BWG T } \\
(\mathrm{kg})\end{array}$ \\
\hline T1 (Control) & $29.46^{\mathrm{a}} \pm 0.94$ & $2.65^{\mathrm{a}} \pm 0.12$ & $2.80^{\mathrm{a}} \pm 0.46$ & $2.15^{\mathrm{a}} \pm 0.17$ & $7.60^{\mathrm{a}} \pm 0.42$ \\
\hline $\begin{array}{l}\text { T2 (3mg FA } \\
\text { supple.) }\end{array}$ & $31.26^{\mathrm{a}} \pm 1.17$ & $2.90^{\mathrm{a}} \pm 0.20$ & $2.95^{\mathrm{a}} \pm 0.37$ & $2.33^{\mathrm{a}} \pm 0.23$ & $8.18^{a} \pm 0.28$ \\
\hline $\begin{array}{l}\text { T3 (6mg FA } \\
\text { supple.) }\end{array}$ & $31.54^{\mathrm{a}} \pm 1.28$ & $2.93^{\mathrm{a}} \pm 0.58$ & $3.00^{\mathrm{a}} \pm 0.27$ & $2.63^{\mathrm{a}} \pm 0.42$ & $8.55^{\mathrm{a}} \pm 0.30$ \\
\hline $\begin{array}{l}\text { T4 }(3 \mathrm{mg} / \mathrm{ml} \text { FA } \\
\text { injec.) }\end{array}$ & $30.30^{\mathrm{a}} \pm 1.49$ & $2.94^{\mathrm{a}} \pm 0.25$ & $2.62^{\mathrm{a}} \pm 0.07$ & $2.72^{\mathrm{a}} \pm 0.39$ & $8.28^{a} \pm 0.54$ \\
\hline $\begin{array}{l}\text { T5 (6mg/ml FA } \\
\text { injec.) }\end{array}$ & $29.32^{\mathrm{a}} \pm 1.20$ & $2.38^{\mathrm{a}} \pm 0.131$ & $2.58^{\mathrm{a}} \pm 0.26$ & $2.68^{\mathrm{a}} \pm 0.56$ & $7.63^{\mathrm{a}} \pm 0.57$ \\
\hline
\end{tabular}

The results of testicular dimension before and after slaughtering demonstrated in table (2), (3), (4), and (5) respectively. Testicular high after first, $2^{\mathrm{ND}}$, and $3^{\text {rd }}$ month of treatment increased $(\mathrm{p}<0.05)$ significantly in T3 $(4.82,5.06$, and $5.32 \mathrm{~cm})$ compared to T1 $(3.60,3.94$, and $4.10 \mathrm{~cm})$. While testicular high in each T2, T4, and T5 increased if compared to T1 but not significantly. On the other hand testicular length, width, and circumference in T3 increased $(\mathrm{p}>0.05)$ compared to anther treatment but not significant detected. T2, T4, and T5 also increased compared to $\mathrm{T} 1$ but not significantly. Then testicular high after slaughtering significantly increased in T3 $(4.367 \mathrm{~cm})$ compared to T1 $(2.33 \mathrm{~cm})$, but testicular length and width increased in T3 compared to T1but no significantly. In addition testicular length, width, and high increased in T2, T4, and T5 compared to T1 but not significantly.

Gonadotrophic hormones especially LH and FSH control testicular development, this hormone secretes and releases by the pituitary gland. However the main target of LH and FSH in the testis are sertoli and leydig cells, LH stimulates biosynthesize of androgen mainly testosterone from leydig cells. The development of the male reproduction organs are controlled by testosterone [21]. FA concentration is not correlate $\mathrm{FSH}, \mathrm{LH}$, and testosterone significantly [22]. Therefore, no significant effect reported on testicular length, width, and circumference, and testes weight in our results.

Table 2: Effect of different FA treatments by supplementation and injection on Testes dimensions of Local Karadi male lambs after $1^{\text {st }}$ month (Mean \pm SE).

\begin{tabular}{lllll}
\hline Treatments & $\begin{array}{l}\text { Testicular } \\
\text { length }(\mathbf{c m})\end{array}$ & $\begin{array}{l}\text { Testicular } \\
\text { width }(\mathbf{c m})\end{array}$ & $\begin{array}{l}\text { Testicular high } \\
(\mathbf{c m})\end{array}$ & $\begin{array}{l}\text { Testicular } \\
\text { circumference } \\
(\mathbf{c m})\end{array}$ \\
\hline T1 (Control) & $6.80^{\mathrm{a}} \pm 1.27$ & $3.24^{\mathrm{a}} \pm 0.19$ & $3.60^{\mathrm{b}} \pm 0.38$ & $14.70^{\mathrm{a}} \pm 1.66$ \\
\hline $\begin{array}{l}\text { T2 (3mg FA } \\
\text { supple.) }\end{array}$ & $6.50^{\mathrm{a}} \pm 0.63$ & $3.18^{\mathrm{a}} \pm 0.19$ & $3.90^{\mathrm{ab}} \pm 0.30$ & $15.94{ }^{\mathrm{a}} \pm 1.11$ \\
\hline $\begin{array}{l}\text { T3 (6mg FA } \\
\text { supple.) }\end{array}$ & $8.70^{\mathrm{a}} \pm 1.85$ & $3.72^{\mathrm{a}} \pm 0.16$ & $4.83^{\mathrm{a}} \pm 0.32$ & $17.50^{\mathrm{a}} \pm 0.67$ \\
\hline $\begin{array}{l}\text { T4 (3mg/ml FA } \\
\text { injec.) }\end{array}$ & $6.60^{\mathrm{a}} \pm 0.89$ & $3.54^{\mathrm{a}} \pm 0.19$ & $4.14^{\mathrm{ab}} \pm 0.48$ & $16.14{ }^{\mathrm{a}} \pm 1.07$ \\
\hline
\end{tabular}




\begin{tabular}{|c|c|c|c|c|}
\hline $\begin{array}{l}\text { T5 }(6 \mathrm{mg} / \mathrm{ml} \mathrm{FA} \\
\text { injec.) }\end{array}$ & $7.00^{\mathrm{a}} \pm 0.55$ & $3.30^{\mathrm{a}} \pm 0.16$ & $3.78^{a b} \pm 0.33$ & $15.70^{\mathrm{a}} \pm 1.19$ \\
\hline
\end{tabular}

-small different letters indicated a significant difference between treatments $(\mathrm{p}<0.05)$.

Table 3: Effect of different FA treatments by supplementation and injection on Testes dimensions of Local Karadi male lambs after $2^{\text {nd }}$ month (Mean \pm SE).

\begin{tabular}{lllll}
\hline Treatments & $\begin{array}{l}\text { Testicular } \\
\text { length }(\mathbf{c m})\end{array}$ & $\begin{array}{l}\text { Testicular } \\
\text { width }(\mathbf{c m})\end{array}$ & $\begin{array}{l}\text { Testicular high } \\
(\mathbf{c m})\end{array}$ & $\begin{array}{l}\text { Testicular } \\
\text { circumference } \\
(\mathbf{c m})\end{array}$ \\
\hline T1 (Control) & $7.80^{\mathrm{a}} \pm 0.82$ & $3.46^{\mathrm{a}} \pm 0.23$ & $3.94^{\mathrm{b}} \pm 0.34$ & $16.70^{\mathrm{a}} \pm 1.66$ \\
\hline $\begin{array}{l}\text { T2 (3mg FA } \\
\text { supple.) }\end{array}$ & $8.30^{\mathrm{a}} \pm 0.77$ & $3.94^{\mathrm{a}} \pm 0.21$ & $4.44^{\mathrm{ab}} \pm 0.28$ & $18.50^{\mathrm{a}} \pm 1.43$ \\
\hline $\begin{array}{l}\text { T3 (6mg FA } \\
\text { supple.) }\end{array}$ & $9.10^{\mathrm{a}} \pm 0.53$ & $3.98^{\mathrm{a}} \pm 0.17$ & $5.06^{\mathrm{a}} \pm 0.46$ & $19.60^{\mathrm{a}} \pm 0.93$ \\
\hline $\begin{array}{l}\text { T4 (3mg/ml FA } \\
\text { injec.) }\end{array}$ & $9.00^{\mathrm{a} \pm 0.61}$ & $3.68^{\mathrm{a}} \pm 0.26$ & $4.26^{\mathrm{ab}} \pm 0.31$ & $17.60^{\mathrm{a}} \pm 1.29$ \\
\hline $\begin{array}{l}\text { T5 (6mg/ml FA } \\
\text { injec.) }\end{array}$ & $8.40^{\mathrm{a} \pm 0.81}$ & $3.60^{\mathrm{a}} \pm 0.19$ & $4.10^{\mathrm{ab}} \pm 0.29$ & $17.90^{\mathrm{a}} \pm 1.78$ \\
\hline
\end{tabular}

-small different letters indicated a significant difference between treatments $(\mathrm{p}<0.05)$.

Table 4: Effect of different FA treatments by supplementation and injection on Testes dimensions of Local Karadi male lambs after $3^{\text {rd }}$ month (Mean \pm SE).

\begin{tabular}{lllll}
\hline Treatments & $\begin{array}{l}\text { Testicular } \\
\text { length }(\mathbf{c m})\end{array}$ & $\begin{array}{l}\text { Testicular } \\
\text { width }(\mathbf{c m})\end{array}$ & $\begin{array}{l}\text { Testicular high } \\
(\mathbf{c m})\end{array}$ & $\begin{array}{l}\text { Testicular } \\
\text { circumference } \\
(\mathbf{c m})\end{array}$ \\
\hline T1 (Control) & $8.50^{\mathrm{a} \pm 0.85}$ & $4.08^{\mathrm{a}} \pm 0.18$ & $4.10^{\mathrm{b}} \pm 0.29$ & $18.30^{\mathrm{a}} \pm 1.85$ \\
\hline $\begin{array}{l}\text { T2 (3mg FA } \\
\text { supple.) }\end{array}$ & $9.10^{\mathrm{a}} \pm 0.70$ & $4.38^{\mathrm{a}} \pm 0.27$ & $4.78^{\mathrm{ab}} \pm 0.32$ & $20.70^{\mathrm{a}} \pm 1.30$ \\
\hline $\begin{array}{l}\text { T3 (6mg FA } \\
\text { supple.) }\end{array}$ & $10.00^{\mathrm{a}} \pm 0.35$ & $4.68^{\mathrm{a}} \pm 0.36$ & $5.32^{\mathrm{a}} \pm 0.41$ & $21.50^{\mathrm{a}} \pm 0.67$ \\
\hline $\begin{array}{l}\text { T4 (3mg/ml FA } \\
\text { injec.) }\end{array}$ & $9.40^{\mathrm{a}} \pm 0.58$ & $4.26^{\mathrm{a}} \pm 0.36$ & $4.92^{\mathrm{ab}} \pm 0.43$ & $20.20^{\mathrm{a}} \pm 1.31$ \\
\hline $\begin{array}{l}\text { T5 (6mg/ml FA } \\
\text { injec.) }\end{array}$ & $8.70^{\mathrm{a} \pm 0.60}$ & $4.14^{\mathrm{a}} \pm 0.13$ & $4.36^{\mathrm{ab}} \pm 0.26$ & $19.90^{\mathrm{a}} \pm 1.17$ \\
\hline -small different letters indicated a significant difference between treatments $(\mathrm{p}<0.05)$. & \\
\hline
\end{tabular}


Table 5: Effect of different FA as supplementation and injection on Testis size of local Karadi male lambs after slaughtering (Mean \pm SE)

\begin{tabular}{llll}
\hline Treatments & $\begin{array}{l}\text { Testis length } \\
(\mathbf{c m})\end{array}$ & Testis width $(\mathbf{c m})$ & Testis High $(\mathbf{c m})$ \\
\hline T1 (Control) & $4.667^{\mathrm{a}} \pm 1.17$ & $3.73^{\mathrm{a}} \pm 0.48$ & $2.33^{\mathrm{b}} \pm 0.33$ \\
\hline T2 (3mg FA supple.) & $5.700^{\mathrm{a}} \pm 1.15$ & $4.23^{\mathrm{a}} \pm 0.42$ & $3.63^{\mathrm{ab}} \pm 0.88$ \\
\hline T3 (6mg FA supple.) & $6.867^{\mathrm{a}} \pm 0.43$ & $4.53^{\mathrm{a}} \pm 0.19$ & $4.37^{\mathrm{a}} \pm 0.23$ \\
\hline T4 (3mg/ml FA inject.) & $5.933^{\mathrm{a}} \pm 0.47$ & $4.30^{\mathrm{a}} \pm 0.46$ & $3.87^{\mathrm{ab}} \pm 0.59$ \\
\hline T5 (6mg/ml FA inject.) & $5.067^{\mathrm{a}} \pm 0.58$ & $4.27^{\mathrm{a}} \pm 0.52$ & $3.47^{\mathrm{ab}} \pm 0.49$ \\
\hline -small different letters indicated a significant difference between treatments $(\mathrm{p}<0.05)$.
\end{tabular}

-small different letters indicated a significant difference between treatments $(\mathrm{p}<0.05)$.

The results of table (6) showed that no significant difference $(\mathrm{p}>0.05)$ reported in Testicular weight between treatments. Testicular weight in T3 increased compared to other treatments but not significant increase reported, in addition Testicular weight in T2, T4, and T5 increased compared to $\mathrm{T} 1$ but significantly no different detected. Because there was not significant difference observed in testis size, therefore not significant difference observed in testicular weight after slaughtering.

Table 6: Effect of different FA as supplementation and injection on Testicular weight of local Karadi male lambs after slaughtering (Mean \pm SE).

\begin{tabular}{llll}
\hline Treatments & $\begin{array}{l}\text { Right testis weight } \\
(\mathbf{g m})\end{array}$ & $\begin{array}{l}\text { Left testis weight } \\
(\mathbf{g m})\end{array}$ & $\begin{array}{l}\text { Both testis weight } \\
(\mathbf{g m})\end{array}$ \\
\hline T1 (Control) & $41.67^{\mathrm{a}} \pm 17.64$ & $43.333^{\mathrm{a}} \pm 19.22$ & $85.00^{\mathrm{a}} \pm 36.88$ \\
\hline T2 (3mg FA supple.) & $50.00^{\mathrm{a}} \pm 20.21$ & $51.67^{\mathrm{a}} \pm 21.67$ & $101.67^{\mathrm{a}} \pm 41.87$ \\
\hline T3 (6mg FA supple.) & $55.00^{\mathrm{a}} \pm 20.82$ & $51.67^{\mathrm{a}} \pm 19.22$ & $106.67 \pm 40.04$ \\
\hline T4 (3mg/ml FA inject.) & $43.33^{\mathrm{a}} \pm 16.41$ & $46.67^{\mathrm{a}} \pm 14.81$ & $90.00^{\mathrm{a}} \pm 31.22$ \\
\hline T5 (6mg/ml FA inject.) & $43.33^{\mathrm{a}} \pm 16.41$ & $48.33^{\mathrm{a}} \pm 16.41$ & $91.67^{\mathrm{a}} \pm 32.83$ \\
\hline
\end{tabular}

-small different letters indicated not significant difference between treatments $(\mathrm{p}>0.05)$.

Table (7): Demonstrated that comparison between treatments in testosterone concentration in the blood significantly no difference $(\mathrm{p}>0.05)$ observed after $1^{\text {st }}, 2^{\text {nd }}$, and $3^{\text {rd }}$ months of experiment. Testosterone concentration after third month of treatment increased when used FA $6 \mathrm{mg}$ as supplementation, $3 \mathrm{mg} / \mathrm{ml}$ as injection but not significantly, also testosterone concentration increased when used Folic acid $6 \mathrm{mg}$ as injection after each month of treatments but not significantly. Because FA is important for DNA synthesize, transfer of RNA and protein [23]. On the other hand, testosterone synthesis biologically from cholesterol. The metabolic steps needed for the conversion of cholesterols into the testosterone take place in leydig cells, and the adrenal cortex [24]. Therefore, no significant change observed in blood testosterone concentration. 
Table 7: Effect of different FA as supplementary and injection on testosterone concentration in blood of local Karadi male lambs (Mean \pm SE).

Testosterone Concentration (ng/ml)

\begin{tabular}{llll}
\hline Treatments & After one month & After two months & After three months \\
\hline T1 (Control) & $0.48^{\mathrm{a}} \pm 0.19$ & $0.47^{\mathrm{a}} \pm 0.10$ & $1.02^{\mathrm{a}} \pm 0.40$ \\
\hline T2 (3mg FA supple.) & $0.50^{\mathrm{a}} \pm 0.06$ & $0.53^{\mathrm{a}} \pm 0.03$ & $1.047^{\mathrm{a}} \pm 0.28$ \\
\hline T3 (6mg FA supple.) & $0.58^{\mathrm{a}} \pm 0.08$ & $0.47^{\mathrm{a}} \pm 0.10$ & $1.57^{\mathrm{a}} \pm 0.05$ \\
\hline T4 (3mg/ml FA inject.) & $0.55^{\mathrm{a}} \pm 0.13$ & $0.76^{\mathrm{a}} \pm 0.14$ & $1.70^{\mathrm{a}} \pm 0.64$ \\
\hline T5 (6mg/ml FA inject.) & $0.64^{\mathrm{a}} \pm 0.09$ & $0.80^{\mathrm{a}} \pm 0.15$ & $1.16^{\mathrm{a}} \pm 0.66$ \\
\hline -small different letters indicated not significant difference between treatments $(\mathrm{p}>0.05)$.
\end{tabular}

Effect of different FA treatments by supplementation and injection on FA concentration in blood of local Karadi male lambs are demonstrated in the table (8), blood FA concentration significantly $(\mathrm{p}<0.05)$ increased in T4 and T5 $(5.703 \pm 0.45,5.637 \pm 0.68)$, compared to T1, T2, and T3 $(2.533 \pm 0.41,3.790 \pm 1.42$, and $3.680 \mathrm{~b} \pm 1.79)$ after one-month treatment. While after two months of treatment there was a significant $(\mathrm{p}<0.05)$ difference observed in both T5 and T4 $(7.560 \pm 1.15$ and $7.477 \pm 0.59)$ if compared to T1, T2, and T3 $(4.833 \pm 0.49,6.67 \pm 2.14$, and $5.560 \pm 0.23)$. T2 and T3 $(6.67 \pm 2.14$ and $5.560 \pm 0.23)$ also significantly increased compare to T1 $(5.560 \pm 0.23)$ after $2^{\text {nd }}$ and $3^{\text {rd }}$ months of treatment. Finally after three months of treatment T5 and T4 $(9.273 \pm 1.28$ and $9.263 \pm 0.47)$ significantly increased compare to T1, T2, and T3 $(4.833 \pm 0.49,6.67 \pm 2.14$, and 5.560 \pm 0.23$)$. T2 and T3 $(6.297 \pm 1.55$ and 5.915 \pm 2.94$)$ respectively increased compared to T1 (3.66 \pm 0.17$)$. The folate content in barley is $0.07-0.68 \mathrm{mg} / \mathrm{kg}$ dry matter [25]. Microorganism degrades more than $97 \%$ of supplementary FA to escape the rumen and absorb by small intestine. However, folates perhaps degraded, converted, and changed in forestomach of ruminant [25]. Therefore, FA by injection increase blood FA concentration, as well as FA supplementary increase blood FA concentration compare to the control. Increased serum Folate associated with taking a high dose of FA, this Data collected from 13 studies on the effect of FA on serum folate concentration [26]. So our result suggests this investigation.

Table 8: Effect of different FA treatments by supplementary and injection on FA concentration in blood of local Karadi male lambs (Mean \pm SE).

FA Concentration (ng/l)

\begin{tabular}{llll}
\hline Treatments & After one month & After two months & After three months \\
\hline T1 (Control) & $2.53^{\mathrm{b}} \pm 0.41$ & $4.50^{\mathrm{b}} \pm 0.29$ & $3.66^{\mathrm{b}} \pm 0.17$ \\
\hline T2 (3mg FA supple.) & $3.79^{\mathrm{ab}} \pm 1.42$ & $6.55^{\mathrm{ab}} \pm 2.14$ & $6.30^{\mathrm{ab}} \pm 1.55$ \\
\hline T3 (6mg FA supple.) & $3.68^{\mathrm{ab}} \pm 1.04$ & $5.56^{\mathrm{ab}} \pm 0.23$ & $5.92^{\mathrm{ab}} \pm 2.94$ \\
\hline T4 (3mg/ml FA inject.) & $5.70^{\mathrm{a}} \pm 0.45$ & $7.48^{\mathrm{ab}} \pm 0.59$ & $9.26^{\mathrm{a}} \pm 0.47$ \\
\hline T5 (6mg/ml FA iniect.) & $5.64^{\mathrm{a}} \pm 0.68$ & $8.36^{\mathrm{a}} \pm 0.73$ & $9.27^{\mathrm{a}} \pm 1.28$ \\
\hline -small different letters indicated a significant difference between treatments $(\mathrm{p}<0.05)$.
\end{tabular}

The result of table (9) showed that diameter of seminiferous tubules, seminiferous tubules circumference, germ cell thickness, and lumen diameter not significant $(p>0.05)$ different detected by different Folic acid treatments as supplementation and injection. The normal spermatogenesis is testosterone dependent [26]. The main androgens are essential for the development and maintenance of specific reproductive tissue testes, epididymis, prostate, seminal vesicle, and penis [24]. In our research testosterone level, not increased significantly, therefore not significant change observed in seminiferous tubules. On the other hand, we used only barley as diet that another reason. 
Table 9: The effect of different Folic acid treatments by supplementary and injection on seminiferous tubules of local Karadi male lambs (Mean \pm SE).

\begin{tabular}{lllll}
\hline Treatments & $\begin{array}{l}\text { Seminiferous } \\
\text { diameter } \\
\left(\mathrm{mm} \times 10^{10}\right)\end{array}$ & $\begin{array}{l}\text { Seminiferous } \\
\text { circumference } \\
(\mathrm{p}<0.05)\end{array}$ & $\begin{array}{l}\text { Germ cell } \\
\text { thickness } \\
(\mathrm{p}<0.05)\end{array}$ & $\begin{array}{l}\text { Lumen diameter } \\
(\mathrm{p}<0.05)\end{array}$ \\
\hline T1 (Control) & $1.26^{\mathrm{a}} \pm 0.25$ & $3.97^{\mathrm{a}} \pm 1.08$ & $0.25^{\mathrm{a}} \pm 0.08$ & $0.45^{\mathrm{a}} \pm 0.13$ \\
\hline T2 (3mg FA supple.) & $1.36^{\mathrm{a}} \pm 0.31$ & $4.00^{\mathrm{a}} \pm 0.82$ & $0.29^{\mathrm{a}} \pm 0.07$ & $0.49^{\mathrm{a}} \pm 020$ \\
\hline T3 (6mg FA supple.) & $1.44^{\mathrm{a}} \pm 0.11$ & $4.42^{\mathrm{a}} \pm 0.43$ & $0.29^{\mathrm{a}} \pm 0.03$ & $0.72^{\mathrm{a}} \pm 0.08$ \\
\hline T4 (3mg/ml FA inject.) & $1.54^{\mathrm{a}} \pm 0.31$ & $4.64^{\mathrm{a}} \pm 0.97$ & $0.35^{\mathrm{a}} \pm 0.05$ & $0.62^{\mathrm{a}} \pm 0.17$ \\
\hline T5 (6mg/ml FA inject.) & $1.14^{\mathrm{a}} \pm 0.23$ & $3.45^{\mathrm{a}} \pm 0.58$ & $0.25^{\mathrm{a}} \pm 0.02$ & $0.49^{\mathrm{a}} \pm 0.14$ \\
\hline
\end{tabular}

-small different letters indicated no significant difference between treatments $(\mathrm{p}>0.05)$.

\section{CONCLUSION}

In conclusion, BW, BWG, and BWGT significantly not difference observed between treatments by using FA as supplementation and injection. Testicular size before slaughtering significantly not different reported in testicular length, testicular width, and testicular Circumference; however, testicular high significantly increased when used FA 3mg as supplementation compared to control after each period of treatments. After slaughtering both testicular size (testis length, testis width, and testis High) and testes weight also significantly not different reported. Testosterone concentration after each month of treatment significantly not changed. FA concentration in blood significantly $(\mathrm{p}<0.05)$ increased when used FA by injection compared to control after $1^{\text {st }}$ and $3^{\text {rd }}$ month of treatment, but after second month of treatment FA concentration in blood increased significantly compare to control when used FA $5 \mathrm{mg} / \mathrm{ml}$ as injection. While FA as supplementation significantly not effected on FA concentration in blood after each period of treatment. Finally, FA by injection and supplementation significantly not affected on seminiferous diameter, seminiferous circumference, germ cell thickness, and lumen diameters after each month of treatments.

\section{REFERENCE}

[1] E. Gootwine, "Genetics and breeding of sheep and goats," Animal Agriculture, pp. 183-198, 2020.

[2] J. De Combellas, "PRODUCTION AND REPRODUCTION PARAMETERS OF TROPICAL SHEEP BREEDS IN IMPROVED PRODUCTION SYSTEMS,” Trop Anim Prod, vol. 5, p. 3, 1980, Accessed: Jan. $02,2021$.

[3] E. Tadesse, T. Negesse, and G. Abebe, "Sheep production and marketing system in southern Ethiopia: the case of Awassazuria district," Tropical Animal Health and Production, vol. 47, no. 7, pp. 1417-1425, May 2015.

[4] S. T. Morris, "Economics of sheep production," Small Ruminant Research, vol. 86, no. 1, pp. 59-62, Oct. 2009.

[5] E. N. Ponnampalam, B. Holman, and N. Scollan, "Sheep: Meat," Encyclopedia of food and health, pp. 750757, 2016.

[6] A. Mohapatra, A. K. Shinde, and R. Singh, "Sheep milk: A pertinent functional food," Small Ruminant Research, vol. 181, pp. 6-11, Dec. 2019.

[7] K. O.Aziz, "A STUDY ON FLEECE CHARACTERIZATION OF HAMADANI SHEEP IN ERBIL PLAIN," Mesopotamia Journal of Agriculture, vol. 33, no. 1, pp. 3-12, Mar. 2005.

[8] A. I. Zugno et al., "Effect of folic acid on oxidative stress and behavioral changes in the animal model of schizophrenia induced by ketamine," J. Psychiatr. Res., vol. 81, pp. 23-35, 2016.

[9] A. Ly et al., "Maternal folic acid supplementation modulates DNA methylation and gene expression in the rat offspring in a gestation period-dependent and organ-specific manner," The Journal of Nutritional Biochemistry, vol. 33, pp. 103-110, Jul. 2016.

[10] U. Laval and A. Canada, "EFFECTS OF A PARENTERAL SUPPLEMENT OF FOLIC ACID AND ITS INTERACTION WITH LEVEL OF FEED INTAKE ON HEPATIC TISSUES AND GROWTH PERFORMANCE OF YOUNG DAIRY HEIFERS,” pp. 1657-1666, 1990. 
[11] F. Scaglione and G. Panzavolta, "Folate, folic acid and 5-methyltetrahydrofolate are not the same thing," Xenobiotica; the fate of foreign compounds in biological systems, vol. 44, no. 5, pp. 480-8, 2014.

[12] I. F. Tagbo and D. C. Hill, "Effect of folic acid deficiency on pregnant rats and their offspring," Canadian Journal of Physiology and Pharmacology, vol. 55, no. 3, pp. 427-433, Jun. 1977.

[13] H. Q. Li et al., "Effects of rumen-protected folic acid addition in maternal and post-weaning diets on growth performance, total tract digestibility, ruminal fermentation and blood metabolites in lambs," Animal Feed Science and Technology, vol. 260, p. 114364, Feb. 2020.

[14] E. S. P. B. V and A. Canada, "Dietary supplements of folic acid: blood and growth responses of white veal calves," vol. 34, no. 402, pp. 71-82, 1993

[15] B. Wang et al., "ScienceDirect Maternal folic acid supplementation modulates the growth performance, muscle development and immunity of Hu sheep offspring of different litter size t3," J. Nutr. Biochem., vol. 70, pp. 194-201, 2019.

[16] M. I. Yousef, F. M. El-demerdash, K. I. Kamil, and F. A. M. Elaswad, "Ameliorating effect of folic acid on chromium ( VI ) -induced changes in reproductive performance and seminal plasma biochemistry in male rabbits," vol. 21, pp. 322-328, 2006.

[17] G. W. Zhang et al., "Effects of folic acid and sodium selenite on growth performance, nutrient digestion, ruminal fermentation and urinary excretion of purine derivatives in Holstein dairy calves," Livestock Science, vol. 231, p. 103884, Jan. 2020.

[18] A. Preynat et al., "Effects of supplementary folic acid and vitamin B12 on hepatic metabolism of dairy cows according to methionine supply," J. Dairy Sci., vol. 93, no. 5, pp. 2130-2142, 2010.

[19] Y. Yao et al., "Effect of dietary folic acid supplementation on growth performance and hepatic protein metabolism in early-weaned intrauterine growth retardation piglets," J. Integr. Agric., vol. 12, no. 5, pp. 862868, 2013.

[20] J. J. Matte, C. L. Girard, and G. F. Tremblay, "Effect of long-term addition of folic acid on folate status, growth performance, puberty attainment, and reproductive capacity of gilts 1," Journal of Animal Science, vol. 71, no. 1, pp. 151-157, Jan. 1993.

[21] C. A. P. Matos and D. L. Thomas, "Physiology and genetics of testicular size in sheep: a review," Livestock Production Science, vol. 32, no. 1, pp. 1-30, Aug. 1992.

[22] T.-L. Yin et al., "Folic acid supplementation as adjunctive treatment premature ejaculation," Medical Hypotheses, vol. 76, no. 3, pp. 414-416, Mar. 2011.

[23] I. M. W. EBISCH, F. H. PIERIK, F. H. DE JONG, C. M. G. THOMAS, and R. P. M. STEEGERSTHEUNISSEN, "Does folic acid and zinc sulphate intervention affect endocrine parameters and sperm characteristics in men?," International Journal of Andrology, vol. 29, no. 2, pp. 339-345, Apr. 2006.

[24] F. F. G. Rommerts, "Testosterone: An overview of biosynthesis, transport, metabolism and nongenomic actions," Testosterone, pp. 1-31, 1998, doi: 10.1007/978-3-642-72185-4_1.

[25] V. Ragaller, L. Hüther, and P. Lebzien, "Folic acid in ruminant nutrition: a review," British Journal of Nutrition, vol. 101, no. 2, pp. 153-164, Sep. 2008.

[26] N. Wald, M. Law, J. Morris, and D. Wald, "Quantifying the effect of folic acid," The Lancet, vol. 358, no. 9298, pp. 2069-2073, Dec. 2001, doi: 10.1016/s0140-6736(01)07104-5. 